\title{
Snow Brand Milk Crossed the Divide between Institutional and Competitive Isomorphism
}

\author{
Ayako AIZAWA ${ }^{\text {a) }}$
}

\begin{abstract}
The development and diffusion of compliance activities in Japanese companies from around 2000 can be thought of as a typical example of the institutional isomorphism discussed by DiMaggio and Powell (1983), that is, isomorphism mechanisms that were at work irrespective of performance (Aizawa, 2018a). Snow Brand Milk Products had a corporate scandal in 2000 , and the compliance activities it began soon after comprised institutional isomorphism. In actuality, at that time there was no extraordinary worsening of performance, though directly after the scandal in 2002, the company was beset by a worsening of performance that put the company in danger, and it waged its survival on a wide-ranging rethinking of the details of its compliance activities to make them more unique. In addition, it spun off core businesses and transferred some of its shares in order to win back trust. Companies that have confronted management crises and have survived work toward restoring trust
\end{abstract}

a) Graduate School of Economics, University of Tokyo, Hongo, Bunkyo-ku, Tokyo, Japan, a-aizawa@g.ecc.u-tokyo.ac.jp

A version of this paper was presented at the ABAS Conference 2018 Summer (Aizawa, 2018b).

(C) 2018 Ayako Aizawa. This is an Open Access article distributed under the terms of the Creative Commons Attribution License, which permits unrestricted reuse, distribution, and reproduction in any medium, provided the original work is properly cited. 
using similar methods. In other words, even when the same company doesn't have selection pressures, institutional isomorphism may arise, and when there are selection pressures, competitive isomorphism may arise.

Keywords: compliance, institutional isomorphism, competitive isomorphism, corporate scandals

\section{Introduction}

According to Aizawa (2018a), the compliance activities of Japanese companies are typical examples of institutional isomorphism. Institutional isomorphism was discussed by DiMaggio and Powell (1983) ${ }^{1}$ as an organizational theory in the New Institutionalism of Meyer and Rowan (1977). Progressive isomorphism as a result of natural selection differs from competitive isomorphism, and institutional isomorphism progresses through the separate and independent mechanism of performance. There are said to be three types of isomorphism: coercive, mimetic, and normative (Takahashi, 2010). Mechanisms of each of these have been at work in the compliance activities of Japanese firms.

Institutional isomorphism is not linked to performance. In fact, many Japanese companies have created specialized departments for compliance, maintaining various systems and rules related compliance in company workplaces, and have also implemented various types of training. However, there are questions as to the effects of such activities, and cases of scandals in large companies as

1 Further, DiMaggio and Powell took Weber's concept of the "iron cage" and stated that isomorphism impacts corporate activities, though in recent years the mistaken "iron cage" translation of Talcott Parsons has been said to be "gehäuse" in Weber's original German, which should be translated as "shell" (Takahashi, 2015). 
Table 1. Mechanism of isomorphic organizational change

competitive isomorphism

institutional isomorphism

coercive isomorphism

mimetic isomorphism

normative isomorphism

well as their aggressive compliance activities attest to that (Kobelco Steel Group, 2017; Toshiba Corporation Third Party Committee, 2015).

On the other hand, however, are there no changes to institutional isomorphism even when performance is in crisis? Based on an investigation of public documents and officials of Snow Brand Milk regarding the two scandals within that company, this paper aims to identify the emergence of institutional isomorphism for the initial scandal and competitive isomorphism for the second, and points out the possibility that performance at the time of crisis is what caused the company to cross that divide.

\section{Corporate Scandals}

Snow Brand Milk Products Co., Ltd. (below, "Snow Brand Milk") is a food manufacturer that was established in 1925. Because of the two company scandals, the company later went through a merger and changed its name, and it has continued with food as its primary business. The company was originally established as a dairy cooperative in Hokkaido, in the spirit of "building land, building people." In the year prior to the occurrence of the first scandal, the company had 12,877 employees, and its consolidated sales were 1.2877 trillion yen. It was a leading company in its industry (Mead, 
Wolfe, Saito, \& Koehn, 2010). Snow Brand Milk, as an industry-leading manufacturer of foods, had an incident of food poisoning in its low-fat milk in 2000. This provided the impetus for the Keidanren and government to put their energies into compliance activities. This food poisoning incident occurred in the milk sold by Snow Brand Milk in the western part of Japan in June 2000, but Snow Brand Milk dragged its feet into responding, and the food poisoning then occurred on a greater scale, expanding nationwide (Hokkaido Shimbun Syuzaihan, 2002).

In addition, at the time the incident was thought to have occurred in the manufacturing unit at the Osaka plant that made the low-fat milk products, yet a later investigation showed that the Hokkaido plant that made the raw materials was in fact the source. It was not Snow Brand Milk that discovered the cause, but rather an investigation by the Osaka Prefectural Police that had also pinpointed the Osaka plant. There are various reasons as to why the company was slow to grasp the incident of the situation. According to the interviews, causal factors were delays in sharing information internally as well as poor ventilation. Snow Brand Milk at the time had the Hokkaido plant, which was responsible for raw materials, and the Osaka plant, which was responsible for the final low-fat milk products. These two plants were in different business units: Business Unit A, responsible for the Osaka plant, and Business Unit $B$, responsible for the Hokkaido plant. Business Unit A was a core business unit from the company's founding, while Business Unit B was created after Business Unit A and focused on processed products. Perhaps because of this relationship, internally the company had a vertically divided organization, with insufficient collaboration between the business units. In actuality, the following three factors have been raised in Snow Brand Milk retrospectives on factors in the 2000 food poisoning incident (Hirata, 2007). 
1) The company structure was internally focused (company thought process, lack of corporate ethics)

2) Weakness of the overall company in understanding the vertical nature of the organizations and in confirming those facts

3) Lack of risk management (hardening of the information arteries and poor responses to results)

Snow Brand Milk had this major food poisoning incident in 2000, and two years later in 2002, it had a food mislabeling incident. The source of this incident was a subsidiary of Snow Brand Milk, though it was first uncovered by an external announcement made by a trading partner of that subsidiary. Because it was the partner that was forced to be complicit in this scandal that made the public announcement, and also because Snow Brand Milk had had the food poisoning incident only two years ago, Snow Brand Milk faced strong criticism. As a result, the company's business quickly worsened, and in 2002, the share prices of Snow Brand Milk dropped as much as $70 \%$ below their pre-incident levels (Mead et al., 2010).

\section{Compliance Activities and Change of an Organization}

Having created a scandal in 2000, Snow Brand Milk began compliance activities shortly thereafter. These activities took the form of institutional isomorphism as other companies, including "creation of a corporate code of ethics," "formation of a compliance committee," and "establishing an external and internal whistleblower desk". However, beset by poor economic performance that hit crisis levels after the 2002 scandal, the company was forced to divest the subsidiary that had caused the problem. The management team took responsibility and resigned, and the company brought on an external director from an external consumer organization to act as the chair of a compliance committee as well as reviewed a broad range of 
Table 2. Change of X's compliance activity

\begin{tabular}{|c|c|c|}
\hline & $\begin{array}{l}\text { after first corporate scandal } \\
\qquad\left(2000^{-}\right)\end{array}$ & $\begin{array}{l}\text { after second corporate scandal } \\
\qquad(2002-)\end{array}$ \\
\hline code of ethics & $\begin{array}{l}\text { outsourcing externally to an } \\
\text { advertisement company }\end{array}$ & $\begin{array}{l}\text { in-house based on } \\
\text { questionnaires }\end{array}$ \\
\hline $\begin{array}{l}\text { committee of } \\
\text { compliance }\end{array}$ & $\begin{array}{l}\text { held as a management } \\
\text { advisory committee }\end{array}$ & $\begin{array}{l}\text { held monthly with outside } \\
\text { director as chairperson }\end{array}$ \\
\hline $\begin{array}{l}\text { compliance } \\
\text { training }\end{array}$ & only training by layers & $\begin{array}{l}\text { small group training } \\
\text { bimonthly, hold "jiken wo } \\
\text { fukasasenai katudou" twice a } \\
\text { year }\end{array}$ \\
\hline $\begin{array}{l}\text { whistle-blowing } \\
\text { system }\end{array}$ & established according to law & $\begin{array}{l}\text { established according to law, } \\
\text { discloses number of report and } \\
\text { content of major classification }\end{array}$ \\
\hline CSR & independent activity & integrated activity \\
\hline
\end{tabular}

compliance activities. ${ }^{2}$ While the framework of the institution itself did not change, details did, and Table 2 summarizes these differences.

At the time in 2000, the company had outsourced the creation of a code of ethics to an outside advertising firm, yet the company feared that the code of ethics had not diffused among employees. The company then decided to create the code of ethics internally, based on an employee questionnaire. Snow Brand Milk had a compliance committee that met monthly versus once or twice per year at other

2 Inviting the external director as a consumer representative was proposed by Koji Morioka, acting as a shareholder ombudsman. The invitation of the consumer agency that previously had nothing to do with the company was opposed by some, but in the end resulted in a more aggressive compliance (Hiwasa, 2003). 
firms, and the committee was very active, it even proffered advice to the president (Hiwasa, 2003). Compliance training consisted of ethics training in small, on-site groups every month (every other month starting in 2017) to ensure the diffusion of the code of ethics. Because the ethics training recommended by the Keidanren is held once a year, Snow Brand Milk would appear to be doing a great deal of training. In addition, regulations required the creation of internal and external whistleblowing desks and CSR reports, which have all been made public, showing the number of incidents reported in each major category. For this scandal as well, the company held special training sessions twice a year on the days of the year in which the incidents were uncovered in 2000 and 2002 as "a way to ensure these incidents are not forgotten" (Megmilk Snow Brand Group, 2017).

One other major organizational action taken by Snow Brand Milk is the decision to sell off a portion of its shares and core businesses. Rebuilding the company's business itself of course began after 2000; however, after the 2002 incident, Snow Brand Milk made the decision to sell off its shi'nyuu (milk) division. ${ }^{3}$ Specifically, by integrating its shi'nyuu division and Nationwide Direct Sales Co., Ltd. and Japan Milk Net Co., Ltd., 4 Snow Brand Milk formed a new company, that is Megmilk Snow Brand Co., Ltd. (henceforth, "Megmilk"), and had Megmilk manufacture and sell shi'nyuu (Megmilk Snow Brand Group, 2017). The merchandizes for which Megmilk took responsibility would include a new brand name as this move was meant to terminate the old brand with Snow Brand Milk. For Snow Brand Milk, which originated from a dairy cooperative, the shi'nyuu division was the center of its business. However, it is believed that the company made this decision in order to survive and

3 This term refers to milk.

4 Japan Milk Net Co., Ltd. was formed in 1996 as a wholly-owned subsidiary of the National Dairy Cooperative Association. 
restore the trust of customers. It resulted in the divested Megmilk afterward, continuing on in the business. Snow Brand Milk established a joint stock company with Megmilk in 2009, and two years later it was able to get back its core business through a merger with Megmilk in 2011. This was ten years after the incident, and it did show that the divestiture made possible the continuation of the business.

\section{Competitive Isomorphism}

Snow Brand Milk created scandals related to its products in both 2000 and 2002. After the 2002 incident, the company's economic performance worsened to a state of crisis, and from 2000, compliance activities led by the Keidanren and government were rapidly diffused. As interest in corporate scandals heightened (Aizawa, 2018a), the public blowback to Snow Brand Milk, which had had two scandals in a two-year period, increased enormously. There are many nearby alternatives for the food products of Snow Brand Milk, which billed themselves as friends to the consumer, and this made it easy for customers to not purchase their products, leading to a rapid worsening of their economic performance.

Snow Brand Milk found itself in a crisis, and in order to survive, the company reviewed its isomorphed compliance activities, making these activities unique to it. Institutional isomorphism was abandoned, and in the process of taking the step of divesting a core business, we can actually experience competitive isomorphism. There are many examples, like Snow Brand Milk, where companies faced with a business crisis divest core businesses and attempt to restore confidence in the corporate group by leveraging confidence in the divested subsidiary. With the discovery in the recent years that Toshiba Corporation had improper accounting issues, the company sold off its large semiconductor 
business. In the 1990s, Daiwa Securities Co., Ltd., hit with financial crisis, sold off an entity and formed a joint venture with a securities firm in the Sumitomo Mitsui Banking Corporation group. ${ }^{5}$ These can be thought of as cases of a transfirm organization (Takahashi, 2014), rather than a single company acting in response to crisis, that is, competitive isomorphism among companies faced with selection pressures.

\section{Concluding Remarks}

Some point out that discussions on institutional isomorphism have not yet hit the inside of individual organizations (Greenwood \& Hinings, 1996), ${ }^{6}$ and some assert that the focus should be more on differences between individual organizations (Azuma, 2004). ${ }^{7}$ Actually, Snow Brand Milk exhibited institutional isomorphism after the incident in 2000, and competitive isomorphism after the incident in 2002. Even if the same company organization responds to a corporate scandal, it is likely that institutional isomorphism occurs when no selection pressures exist, and competitive isomorphism occurs when selection pressures exist.

In actuality, even when a major scandal occurs, if it has no effect on economic performance, there may be no selection pressure from the market, and institutional isomorphism may arise as in the case of Snow Brand Milk in 2000. For example, (a) if a scandal stems from an accounting issue, such as window dressing numbers, and that

5 Daiwa Securities Co., Ltd. established Daiwa Securities Capital Markets Co., Ltd. in 1999 with the securities division of Sumitomo Mitsui Banking Corporation.

6 Meyer and Rowan (1977) also thought that an organization's institutions differed from actual activities, and that they were loosely integrated (Weick, 1976).

7 Research has been on institutional isomorphism in mobile phone companies in cases of competition among companies (Uenishi, 2014). 
scandal has little impact on customers, or if (b) a scandal is related to a company's products, but those products are difficult to replace, making it difficult for customers to leave, then selection pressures may not arise and the institutional isomorphism that does occur may be of questionable effect.

\section{Acknowledgments}

This work was supported by JSPS Grant-in-Aid for Publication of Scientific Research Results, Grant Number JP16HP2004.

\section{References}

Aizawa, A. (2018a). Institutional isomorphism in Japanese firms' compliance activities. Annals of Business Administrative Science, 17, 57-68. doi: 10.7880/abas.0180130a

Aizawa, A. (2018b, July). Company $X$ crossed the divide between institutional and competitive isomorphism. Paper presented at ABAS Conference 2018 Summer, University of Tokyo, Japan.

Azuma, T. (2004). Seidoha soshikiron no shintenkai: Seidoha soshikiron to soshikihenkaku no kankeisei wo chushinni [New development of institutional organization: Focus on relationship of institutional organization and organizational change]. Kyoto Management Review, 6, 81-97 (in Japanese).

DiMaggio, P. J., \& Powell, W. W. (1983). The iron cage revisited: Institutional isomorphism and collective rationality in organizational fields. American Sociological Review, 48(2), 147-160.

Greenwood, R., \& Hinings, C. R. (1996). Understanding radical organizational change: Bringing together the old and the new institutionalism. Academy of Management Review, 21(4), 1022-1054.

Hirata, M. (2007). Fushojikigyou no keieisaisei: Mitsuibussan to Yukijirushinyugyo no case kara [Management reproduction of 
scandals: From the cases of Mitsui \& Co., Ltd. and Snow Brand Milk Products Co., Ltd.]. Seijoudaigaku Keieigakubu Kenkyukiyou, 4, 3-35 (in Japanese).

Hiwasa, N. (2003). Shohisya undo soshite Yukijirushinyugyo shagaitorishimariyaku he [Consumer activity to the outside director of Snow Brand]. Tokyo, Japan: Coop Shuppan (in Japanese).

Hokkaido Shimbun Shuzaihan. (2002). Kenshou "Yukijirushi" houkai: Sonotoki nani ga okottaka [Inspection "Yukijirushi" collapse: What has happened then?]. Tokyo, Japan: Koudansha Bunko (in Japanese).

Kobelco Steel Group. (2017). Kobelco sustainability report 2017 [Survey report] (in Japanese). Retrieved from http://www.kobelco.co.jp/ about_kobelco/csr/kaiji/report/2017/files/2017csr_report.pdf

Mead, J., Wolfe, R. W., Saito, A., \& Koehn, D. (2010). Yukijirshinyugyo: Kigyo saisei to kongo no kadai [Snow Brand Milk Products Co., Ltd.: Corporate revitalization and future challenge]. Keiei Rinri, 60, 40-56 (in Japanese).

Megmilk Snow Brand Group. (2017). CSR katudo houkokusho 2017 [Survey report] (in Japanese). Retrieved from http://www.megsnow.com/csr/report/pdf/2017/all.pdf

Meyer, J. W., \& Rowan, B. (1977). Institutionalized organizations: Formal structure as myth and ceremony. American Journal of Sociology, 83(2), 340-363.

Takahashi, N. (2010). Dame ni naru kaisya [Getting worse company]. Tokyo, Japan: Chikuma Shinsho (in Japanese).

Takahashi, N. (2014). Transfirm organization view. Annals of Business Administrative Science, 13, 31-46. doi: 10.7880/abas.13.31

Takahashi, N. (2015). Behind the shell: Rigid persons clung onto it. Annals of Business Administrative Science, 14, 1-14. doi: 10.7880/abas.14.1

Toshiba Corporation Third Party Committee. (2015). Chousa houkokusho [Survey report] (in Japanese). Retrieved from https://www.toshiba.co.jp/about/ir/jp/news/20150720_1.pdf

Uenishi, S. (2014). Seidotekidoukeika wo tsujita senryakuteki riakushon: Keitaidenwa sangyo ni okeru hyoujun ni motozuita ishukongo no kyoso [Competitive reaction through institutional isomorphism: A variety mixed competition in cellular phone market based on 
standard]. Keieigakuronsyu, 25(2), 25-45 (in Japanese).

Weick, K. E. (1976). Educational organizations as loosely coupled systems. Administrative Science Quarterly, 21(1), 1-19. 